\title{
Cancer in beluga whales from the St Lawrence Estuary, Quebec, Canada: A potential biomarker of environmental contamination 1
}

\author{
Daniel Martineau*, Stéphane Lair*, Sylvain De Guise+, Thomas P. Lipscomb \\ and Pierre BÉland
}

Contact e-mail: martinea(à ere.umontreal.ca

\begin{abstract}
A population of approximately 500 white whales (Delphinapterus leucus) inhabits a short stretch of the St Lawrence Estuary which drains one of the most industrialised areas of the world. Over a 12-year period (1983-1994), 73 carcasses out of 175 beluga $^{2}$ whales reported stranded on the $\mathrm{St}$ Lawrence Estuary shoreline have been examined. Of these 73 carcasses, $14(19 \%)$ were affected by 15 different malignant tumours (cancers), one animal being affected by two different types of cancer. Overall. $23 \%$ of necropsied sexually mature animals were affected by cancer. Forty percent of the 35 cancer cases reported world-wide in cetaceans occurred in this population. The estimated annual incidence rate (AIR) of cancer in St Lawrence beluga whales, a minimum figure of 23.3/100,000 animals, is much higher than that reported for any other population of cetaceans, and is similar to that of man, and of hospitalised cats and cattle. More specifically, the AIR of small intestinal cancers in the studied population, a minimum figure of $83 / 100,000$ animals, is much higher than that observed in man and all animals, except in sheep in certain parts of the world, where an environmental carcinogen is believed to be etiologically involved.
\end{abstract}

KEYWORDS: POLLUTION-PAHS; WHITE WHALES; BIOMARKERS; DISEASE

\section{INTRODUCTION}

Despite the significant number of post-mortem examinations performed on cetaceans over the last 50 years, a relatively small number of cancers (malignant tumours) have been reported in these animals (e.g. Landy, 1980; Howard et al., 1983; Geraci et al., 1987). In a review of cetacean tumours, Geraci et al. (1987) examined the accuracy of diagnosis of reported neoplasms and concluded that no causal association could be identified between the reviewed tumours and environmental pollutants. Since that publication, most of the additional cases of cetacean cancers have been reported from the small (ca $500-1,000$ animals; Kingsley, 1996) beluga whale population inhabiting the St Lawrence Estuary (Martineau et al., 1988; 1995; Girard et al., 1991; De Guise et al., 1994). It has been

${ }^{1} \mathrm{~A}$ version of this paper was submitted to the IWC workshop on Chemical Pollution and Cetacean, March 1995, Bergen as SC/M95/P10.

${ }^{2}$ The official IWC common name for Delphinapterus leucas is the white whale. However, as the common name used in previous papers relating to this population is the alternative 'beluga whale', this has been retained for this paper.

"Canadian Cooperative Wildlife Health Centre. Département de Pathologie et Microbiologie, Faculté de Médecine Vétérinaire. Université de Montréal, Saint-Hyacinthe, Québec J2S 7C6, Canada.

+ Université du Québec à Montréal, Montréal, C.P. 8888, Succ. A, Montréal, Québec H3C 3P8, Canada.

¥ Dept. of Veterinary Pathology, Armed Forces Institute of Pathology, Washington, DC 20306-6000, USA.

+ St Lawrence National Institute of Ecotoxicology, 460 du Champs de Mars, suite 504, Montréal, Québec H2Y IB4, Canada. 
suggested that this high prevalence might be etiologically related to environmental contaminants (Martineau et al., 1988; 1994; 1995; De Guise et al., 1994). The purpose of this paper is to review reported cases of cancers in free-ranging cetaceans, and to compare the cancer prevalence found in St Lawrence beluga whales with that prevailing in other cetaceans, domestic animals and man. Two new cases of gastrointestinal cancer for cetaceans, a gastric adenocarcinoma and a small intestinal adenocarcinoma are also described.

\section{MATERIALS AND METHODS}

\section{Previously reported cases}

Published cases of cancers reported in free-ranging cetaceans and those listed in the Marine Mammal Database of the Registry of Comparative Pathology (Armed Forces Institute of Pathology (AFIP), Washington DC, 20306) were reviewed. The database includes tissue glands, glass slides, paraffin blocks and photographs from captive and free-ranging marine mammals affected by neoplasia, congenital conditions and diseases caused by parasites, bacteria and viruses. The samples are supplied from the USA and other countries on a voluntary basis by professionals (mostly biologists and veterinarians) involved with marine mammals. At the end of 1995, the database included reference to 834 diseased cetaceans (including 13 of the 14 St Lawrence white whales affected with cancer). Over 90\% $(n=774)$ of the database examples originated from necropsies with the remainder $(n=60)$ from surgical submissions from live animals. In addition to the 13 white whales from St Lawrence a further 14 white whales affected by various diseases were included, all of which were captive. Of these, six were adults $(10,15,19$ and 26 years and two of unknown age but considered 'adults'), one was a new-born (4 days), a second was a juvenile ( 3 months) and the last was immature ( 3 years); the age of five animals was not reported. Samples from all of these whales were obtained from necropsies whilst three came from live diseased animals.

\section{Biological sampling}

Since January 1983,175 beluga whale carcasses have been found drifting or stranded along the shoreline of the St Lawrence Estuary, Quebec, Canada. Some $42 \%(n=73)$ were examined at the Faculté de Médecine Vétérinaire of Université de Montréal, of which $85 \%$ $(n=62)$ were sexually mature.

\section{Cancer epidemiology in St Lawrence beluga whales}

Assuming that the St Lawrence animals are a distinct population, the total incidence of cancers in the studied population during the study period can be expressed as:

$$
\hat{N}_{C}=\frac{N_{c}}{M_{A}} \times M \text { where: }
$$

$\hat{N}_{C}=$ the estimated number of cancers in the population;

$N_{c}=$ the number of autopsied animals with cancer;

$M_{A}=$ the number of autopsied animals; and

$M=$ the estimated minimum total mortality. 
This assumes that the animals that are autopsied are representative of the total stranded 'population'. If it is assumed that all dead animals strand, then $M=M_{s}$, where $M_{s}=$ the number of stranded animals. However, weather conditions in the region mean that strandings can only be detected for 9 months of the year. If it is assumed that mortality is uniform throughout the year then;

$$
M=M_{s} \times \frac{12}{9}
$$

For other species, the parameter usually estimated is the annual incidence rate of cancers (AIR) expressed as the number of cancers per 100,000 individuals. Following Dorn and Priester (1987), for the study population this would be:

$$
A I R=\frac{N_{c}}{T} \times \frac{100,000}{N_{l}}
$$

where $T$ is the study period in years and $N_{t}$ is the estimated total population size. This assumes that $N_{t}$ has been constant over the duration of the study.

The validity of the assumptions involved is discussed later in the paper. A crude sensitivity test is carried out by assuming different values for population size, $N_{t}$, and the correction factor for poor weather (see Tables 4 and 5). The scenarios tested have been termed: 'best' i.e. reflecting our view of the most likely values; 'optimistic' i.e. assumed values that lead to a lower AIR in the population and 'pessimistic'; i.e. assumed values that lead to a higher AIR.

\section{RESULTS}

\section{Cancers reported in cetaceans}

Malignant neoplasms that have been reported in free-ranging cetaceans are listed in Tables 1,2 and 3. A total of only 35 cancers have been reported in two species of Mysticeti and nine species of Odontoceti.

High percentages of those cancers were found in the digestive (12/35 or $35 \%$ ) and reproductive ( $9 / 35$ or $26 \%$ ) systems. The high number of ovarian cancers is probably explained by the emphasis put on the examination of the reproductive system during evaluation of the productivity of commercially exploited species (Geraci et al., 1987).

\section{Cancer incidence in the St Lawrence population}

From equations (1) and (2) above and the parameter values listed in Table 5, the total incidence of animals with cancer in the studied population is about 45 , translating to an AIR of about 750 animals per 100,000 for the 'best' scenario. The results of the sensitivity analysis are considered in the 'Discussion'.

\section{Nature of the cancers in St Lawrence beluga whales}

Two new gastrointestinal cancers

The carcass of an adult male beluga whale (Dl-1-94) was found drifting offshore near Tadoussac $\left(48^{\circ} 7^{\prime} \mathrm{N}, 69^{\circ} 43^{\prime} \mathrm{W}\right)$ on 24 May 1994 . The major finding of the necropsy was a large $(9 \times 7 \times 2 \mathrm{~cm}$ deep) ulcer present on the mucosa of the second gastric compartment. The ulcer was connected to the abdominal cavity by a $7 \mathrm{~mm}$-diameter perforation. Microscopic examination (performed in May 1995) revealed that the tunica submucosa and the tunica muscularis of the gastric wall adjacent to the ulcer were heavily infiltrated by large numbers 
Table 1

Cancers reported in beluga whales from the St Lawrence Estuary (1983-1994).

\begin{tabular}{|c|c|c|c|c|c|c|}
\hline Organ & Cancer type & $\begin{array}{l}\text { Age } \\
\text { (yrs) }\end{array}$ & Sex & Date of stranding & $\begin{array}{l}\text { AFIP } \\
\text { accession no.' }\end{array}$ & Reference \\
\hline $\begin{array}{l}\text { Urinary } \\
\text { bladder }\end{array}$ & $\begin{array}{l}\text { Transitional ccll } \\
\text { carcinoma }\end{array}$ & 17 & M & $1983(\mathrm{Dl}-18-83)^{2}$ & & Martincau et al., 1985 \\
\hline Intestine & Adenocarcinoma & $29+$ & M & 1989 (Dl-7-89) & $2462295-3$ & De Guise et al., 1994 \\
\hline Intestine & Adenocarcinoma & $20+$ & M & $1989(\mathrm{D}]-8-89)$ & $2462247-4$ & De Guise et al, 1994 \\
\hline Intestine & Adenocarcinoma & $25+$ & M & 1993 (Dl-2-93) & 2461200 & Martineau et al., 1995 \\
\hline Intestine & Adenocarcinoma & $27+$ & M & 1994 (Dl-2-94) & $2464226-6$ & Martineau et al., 1995 \\
\hline Intestine & Adenocarcinoma & $27+$ & $\mathbf{F}$ & 1994 (Dl-7-94) & $2508083-900$ & This report \\
\hline Stomach & Adenocarcinoma & $21+$ & $\mathrm{F}$ & 1988 (Dl-4-88) & $2456949-3$ & De Guise et al., 1994 \\
\hline Stomach & Adenocarcinoma & $27+$ & M & 1994 (Dl-1-94) & $2508095-300$ & This report \\
\hline Salivary gland & Adenocarcinoma & 24 & M & 1986 (Dl-6-86) & $2457053-3$ & Girard et al., 1991 \\
\hline Liver & Adenocarcinoma & $22+$ & $\mathrm{F}$ & $1988(\mathrm{Dl}-9-88)^{3}$ & $2456952-7$ & De Guise et al., 1994 \\
\hline $\begin{array}{l}\text { Mammary } \\
\text { gland }\end{array}$ & Adenocarcinoma & & & & & \\
\hline Ovary & Granulosa cell tumour & 24.5 & $\mathrm{~F}$ & 1985 (Dl-2-85) & 2519612 & Martineau et al., 1988 \\
\hline Ovary & Granulosa cell tumour & $21+$ & $\mathrm{F}$ & 1988 (Dl-13-88) & $2462292-0$ & De Guise et al., 1994 \\
\hline Ovary & Dysgerminoma ${ }^{4}$ & $25+$ & $\mathrm{F}$ & $1989(\mathrm{Dl}-6-89)$ & $2462229-2$ & De Guise et al., 1994 \\
\hline Mediastinum & $\begin{array}{l}\text { Poorly differentiated } \\
\text { malignant neoplasm } \\
\text { (cancer) }\end{array}$ & $18+$ & M & 1990 (Dl-1-90) & 2519747 & De Guise et al., 1994 \\
\hline
\end{tabular}

${ }^{1}$ All cases have been submitted to the AFIP except Dl-18-83 which has been confirmed by Daniel Cowan, Department of Pathology, University of Texas Medical Branch, Galveston, Texas 77555-0588, USA. This case has also been confirmed in Geraci et al., 1987. ${ }^{2} \mathrm{DI}-18-83$ is the $18^{\text {th }}$ beluga examined in 1983. The same system was used for the classification of all carcasses. ${ }^{3}$ Dl-9-88 was affected by two cancers. ${ }^{+}$Classified as Granulosa Cell Tumor in De Guise et al., 1994. Reclassified as Dysgerminoma after consultation with AFIP. 'Classified as metastatic poorly differentiated carcinoma in De Guise et al., 1994. Reclassified as poorly differentiated neoplasm after consultation with AFIP.

of irregularly-shaped tubular glands separated by moderate amounts of connective tissue (Fig. 1). The tubular structures were lined by closely packed cuboidal cells that generally formed a single layer but occasionally piled up in a disorderly manner (Fig. 2). The tumour cells had varying amounts of eosinophilic cytoplasm and the generally round nuclei were hyperchromatic, often crowded, varied moderately in size and occupied a central position. Chromatin was finely to coarsely clumped and nucleoli could not be seen. The nucleus:cytoplasmic ratio was higher than one. Mitoses were rare. Multifocal aggregates of predominant macrophages were observed in the stroma with small numbers of plasmocytes and neutrophils. Accordingly, a gastric adenocarcinoma with a secondary perforating ulcer was diagnosed.

The carcass of a female beluga whale (D/-7.94) was found at Saint-Paul du Nord $\left(48^{\circ} 34^{\prime} \mathrm{N}, 69^{\circ} 15^{\prime} \mathrm{W}\right)$, on 25 December 1995. During the necropsy, it was found that the duodenal segment wall was diffusely thickened $(3 \mathrm{~cm})$ over a length of $20 \mathrm{~cm}$ at the junction with the stomach. The demarcation between the distal normal intestinal wall $(1 \mathrm{~cm}$ thick) and the thickened segment was abrupt. Microscopically, the intestinal wall was thickened by cellular nodules present mostly in the tunica submucosa. These nodules, separated by an abundant fibrous stroma, were composed of irregularly-sized and poorly-formed tubular glandular structures and nests of tumour cells that were separated by smaller amounts of stroma where single tumour cells were often present. Infiltrating tumour cells were also present in large numbers in the subjacent tunic t muscularis where they formed small 
Table 2

Cancers reported in free-ranging cetaceans, other than St Lawrence beluga whales.

\begin{tabular}{|c|c|c|c|c|c|c|}
\hline Species & Organ & Cancer & Age & Sex & Sources & Reference \\
\hline Bottlenose dolphin & Liver, lungs & Reticuloendotheliosis & & $\mathrm{F}$ & & $\begin{array}{l}\text { Pers. comm. in } \\
\text { Landy, } 1980\end{array}$ \\
\hline Bottlenose dolphin & Pancreas & Carcinoma & Adult & M & & $\begin{array}{l}\text { Pers. comm. in } \\
\text { Landy, } 1980\end{array}$ \\
\hline Bottlenose dolphin & $\begin{array}{l}\text { Spleen. } \\
\text { lymph nodes }\end{array}$ & Lymphosarcoma & Adult & $\mathrm{F}$ & & $\begin{array}{l}\text { Pers comm. in } \\
\text { Landy, } 1980\end{array}$ \\
\hline $\begin{array}{l}\text { Pacific white-sided } \\
\text { dolphin }\end{array}$ & $\begin{array}{l}\text { Spleen. } \\
\text { lymph nodes }\end{array}$ & Lymphosarcoma & Adult & M & & $\begin{array}{l}\text { Howard et al., } \\
1983\end{array}$ \\
\hline $\begin{array}{l}\text { Pacific white-sided } \\
\text { dolphin }\end{array}$ & $\begin{array}{l}\text { Spleen, } \\
\text { lymph nodes, } \\
\text { liver, kidney }\end{array}$ & Eosinophilic leukemia & Adult & M & & $\begin{array}{l}\text { Howard e' al., } \\
1983\end{array}$ \\
\hline Pilot whale & Ovary & Granulosa cell tumour & Adult & $\mathrm{F}$ & & $\begin{array}{l}\text { Bernischke and } \\
\text { Marsh, } 1984\end{array}$ \\
\hline Harbour porpoise & Unknown & Adenocarcinoma & & $\mathrm{F}$ & British waters & $\begin{array}{l}\text { Baker and Martin, } \\
1992\end{array}$ \\
\hline Harbour porpoise & Stomach & Adenocarcinoma & Adult & $\mathrm{F}$ & $\begin{array}{l}\text { Northern } \\
\text { Wadden Sea }\end{array}$ & Breuer et al., 1989 \\
\hline $\begin{array}{l}\text { Amazon river } \\
\text { dolphin }\end{array}$ & Lung & $\begin{array}{l}\text { Squamous cell } \\
\text { carcinoma }\end{array}$ & Adult & $\mathrm{F}$ & & Geraci et al., 1987 \\
\hline Blue whale & Ovary & Granulosa cell tumour & Adult & $\mathrm{F}$ & Antarctic & \\
\hline Fin whale & Ovary & Granulosa cell tumour & Adult & $\mathrm{F}$ & Antarctic & $\begin{array}{l}\text { Rewell and Willis, } \\
1949\end{array}$ \\
\hline Fin whale & Ovary & Granulosa cell tumour & Adult & $\mathrm{F}$ & Antarctic & $\begin{array}{l}\text { Rewell and Willis, } \\
1949\end{array}$ \\
\hline Fin whale & Ovary & Carcinoma $^{1}$ & Adult & $F$ & Antarctic & Stolk, 1952 \\
\hline
\end{tabular}

'Reclassified as Granulosa cell tumour by Geraci et al., 1987.

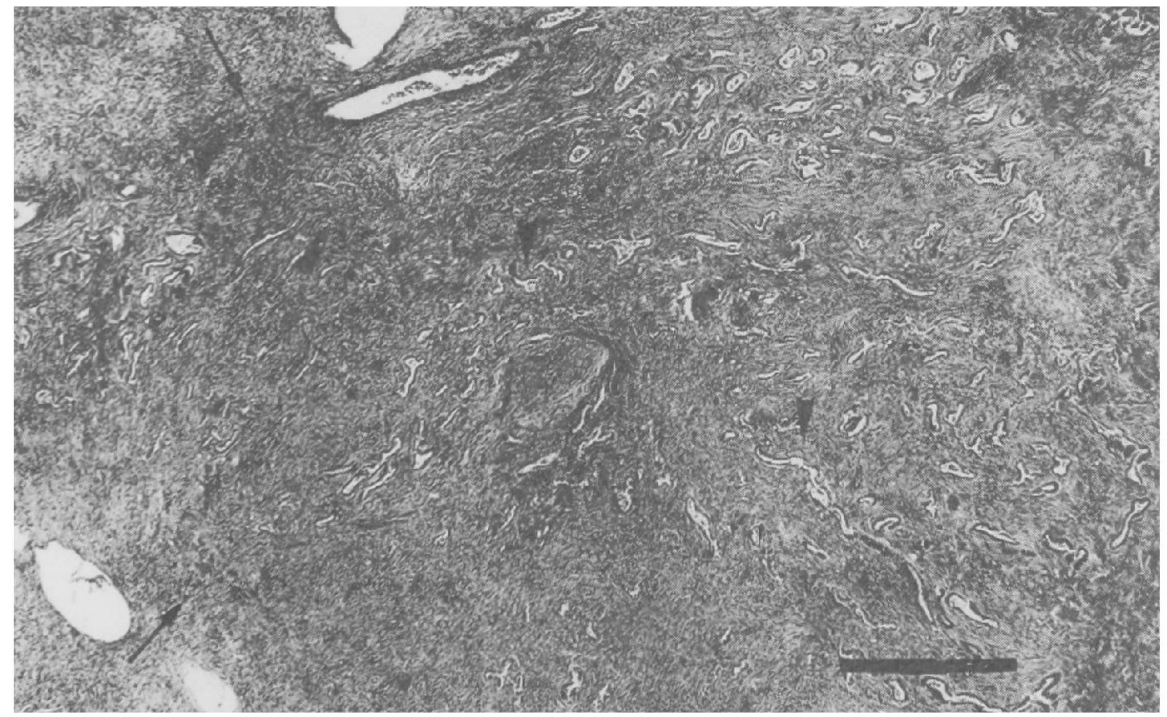

Fig. 1. Gastric adenocarcinoma in a beluga whale (DL-1-94). Numerous irregularly-shaped, tubular, gland-like structures (arrowheads) infiltrate the thir'd submuc'osa of the second gastric compartment and are separated by a moderately abundant collagenous stroma. Arrows show the boundary between the normal tunica submucosa (left and right corners) and the infiltrating tumour cells (right). Bar: $0.5 \mathrm{~mm}$. 
Table 3

Cetaceans affected by cancer listed in the Marine Mammal Database, AFIP (updated, December 1995).

\begin{tabular}{|c|c|c|c|c|c|c|c|c|}
\hline Species & Status & Organ & Cancer type & Age & Sex & Sources & $\%^{1}$ & $\begin{array}{c}\text { Accession } \\
\text { no. }\end{array}$ \\
\hline Beluga & Captive & Brain & Carcinoma & $19 \mathrm{yrs}$ & $\mathrm{M}$ & Arctic & $7.1 \%(14)$ & 2034441 \\
\hline $\begin{array}{l}\text { Bottlenose } \\
\text { dolphin }\end{array}$ & Wild & $\mathbf{U}^{2}$ & $\begin{array}{l}\text { Tubulopapillary } \\
\text { adenocarcinoma }\end{array}$ & Adult & $\mathbf{M}$ & $\begin{array}{l}\text { Gulf of } \\
\text { Mexico }\end{array}$ & $0.3 \%(384)$ & 2304654 \\
\hline $\begin{array}{l}\text { Bottlenose } \\
\text { dolphin }\end{array}$ & Wild & Kidney & Renal cell carcinoma & Adult & $\mathrm{F}$ & $\begin{array}{l}\text { Atlantic Ocean } \\
\text { (S. Carolina) }\end{array}$ & $0.3 \%(384)$ & 2445679 \\
\hline Fin whale & Wild & Kidney & Lymphosarcoma & Adult & $\mathrm{F}$ & $\mathrm{U}$ & $20 \%(5)$ & 1470245 \\
\hline $\begin{array}{l}\text { Killer } \\
\text { whale }\end{array}$ & Captive & $\begin{array}{l}\text { Liver, lymph } \\
\text { node, spleen }\end{array}$ & Reticuloendotheliosis & Adult & $F$ & $U$ & $5.3 \%(19)$ & 162636 \\
\hline $\begin{array}{l}\text { Killer } \\
\text { whale }\end{array}$ & Captive & Lymph node & $\begin{array}{l}\text { Hodgkin's discase- } \\
\text { like }^{3}\end{array}$ & Adult & M & Iceland & $5.3 \%(19)$ & 2337420 \\
\hline $\begin{array}{l}\text { Pygmy } \\
\text { sperm } \\
\text { whale }\end{array}$ & $\mathbf{U}$ & Liver & Cholangiocarcinoma & $\mathbf{U}$ & $\mathrm{U}$ & $\mathrm{U}$ & $1.7 \%(57)$ & 1777514 \\
\hline $\begin{array}{l}\text { Spotted } \\
\text { dolphin }\end{array}$ & Wild & $\begin{array}{l}\text { Testis, lymph } \\
\text { nodes, } \\
\text { adrenal } \\
\text { glands }\end{array}$ & $\begin{array}{l}\text { Malignant } \\
\text { seminoma, } \\
\text { Pheochromocytoma }\end{array}$ & Adult & $\mathrm{M}$ & $\begin{array}{l}\text { Gulf of } \\
\text { Mexico }\end{array}$ & $16.7 \%(6)$ & 2428264 \\
\hline
\end{tabular}

(Number of animals affected by cancers of a given species) over (the total number of animals of this species) $\times 100$; ( ): total number of animals that are listed in the Marine Mammal Database of the AFIP. 'Unknown.

${ }^{3}$ Yonezawa et al., 1989.

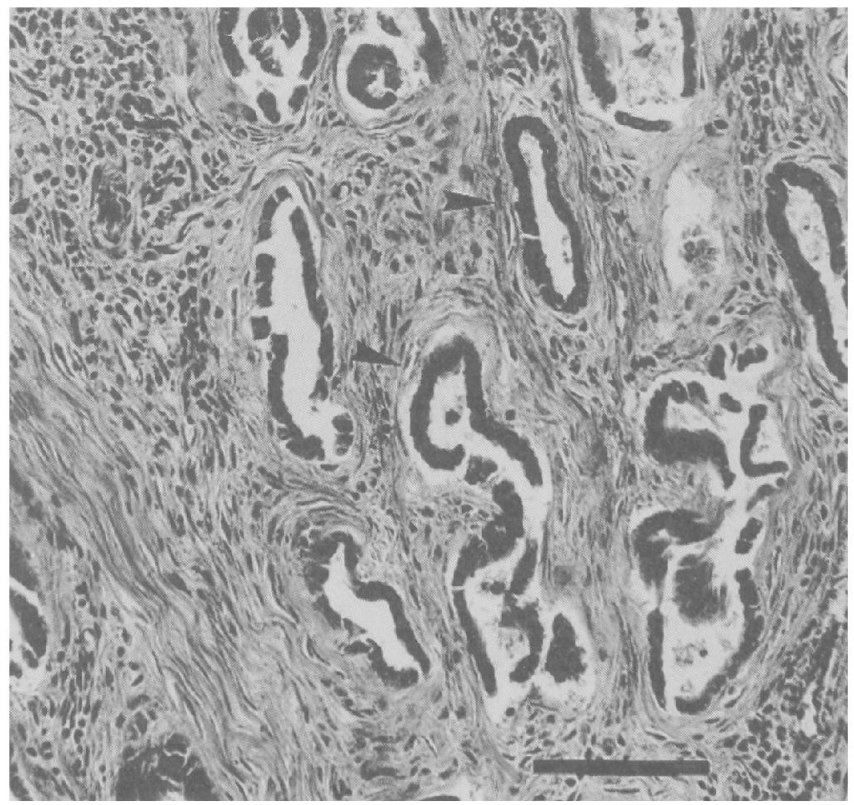

Fig. 2. Gastric adenocarcinoma in a beluga whale (DL-1-94). The glandular structures (arrowhead) are lined by a single layer of well differentiated cuboidal cells. The collagenous stroma contains several interspersed aggregates of mononuclear cells. The apparent delachment of tumour cells into the tubular lumen is due to autolysis. Bar: 100um. 
irregularly-shaped nests or poorly-formed acini with indistinct lumen (Fig. 3). In addition, single tumour cells were generally large, tended to be columnar, were irregularly-sized and shaped and showed loss of polarity. The cytoplasm was scarce, the nucleus:cytoplasm ratio was higher than one and the nuclei were large, variably-shaped and sized. A highly infiltrative small intestinal adenocarcinoma was diagnosed.

\section{Summary of cancer types found}

Fifteen cancers were diagnosed in $14(19 \%)$ of the animals necropsied (Table 1). If only sexually mature adults are considered this rises to 23\% (Martineau et al., 1988; 1994; De Guise et al. 1994). Some $60 \%$ of the malignant tumours originated from the epithelium lining the digestive system (adenocarcinomas of the intestine, stomach, liver and salivary gland) (Girard et al., 1991; De Guise et al., 1994; Martineau et al., 1995). Four intestinal adenocarcinomas were close to the stomachs and one was closer to the anus (Martineau et al., 1995).

\section{DISCUSSION}

\section{Cancers previously reported in cetaceans}

\section{Limitations of the source material}

The published material prior to this study does not comprise a systematic survey of cancer incidence in cetacean populations. Rather it reflects the interest of a relatively small number of scientists, particularly in earlier years. For example, only a tiny proportion of the baleen whales killed for commercial purposes this century, even those flensed with biologists present, were examined for cancer (or indeed any other diseases). This reflected the prevailing interest at that time, which was the estimation of population parameters, particularly with respect to reproduction. The same is true for catches of odontocetes. Thus, whilst the low number of reports might be taken as indicative of the relative rarity of cancer, it is impossible to quantify this in any way.

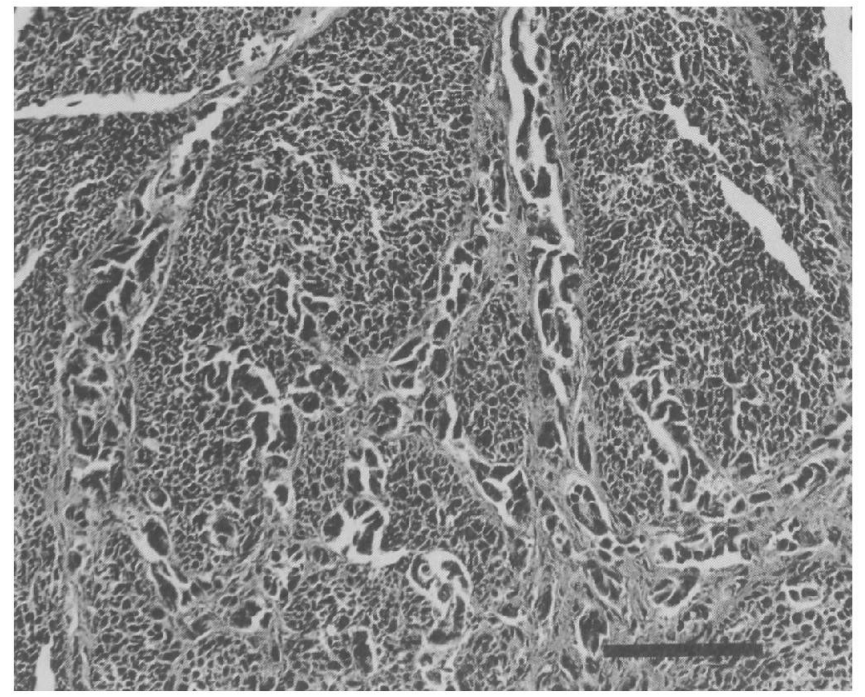

Fig. 3. Smail intestinal (duodenal) adenocarcinoma in a beluga whale (DL-7-94). Multiple poorly-formed glandular structures and nests of epithelial cells infiltrate the duodenal tunica muscularis along fibrous septa. The empty spaces result from autolysis. Bar: $200 \mu \mathrm{m}$. 
However, there have been some relatively systematic studies. For example, a single cancer was found during the post-mortem examination of 301 cetaceans from British waters (J.R. Baker, University of Liverpool, pers. comm.), only one cancer was found by Geraci et al. (1987) in over 1,800 cetaceans examined and no tumours were found in approximately 50 beluga whales examined in the Arctic (D.J. St. Aubin, pers. comm. in De Guise et al., 1994). In two other studies, neither Stroud and Roffe (1979) nor Howard et al. (1983) reported neoplasms from 21 stranded cetaceans and 65 stranded common dolphins (Delphinus delphis), respectively. Philo et al. (1993) reported that only one (apparently non-malignant) tumour had been found in 130 bowhead whales (Balaena mysticetus) examined between 1980 and 1989 , but cautioned that the quality of the examinations were not consistent, depending on the personnel present and the prevailing conditions.

However, there are problems in quantitatively interpreting data from each of the above studies. For most, there is insufficient information available on the animals examined, in terms of how they were selected, associated biological data and their species and population identity. Interpretation of the Arctic beluga data is confounded by the fact that the ages of the animals are not known and, as discussed later, age may be a significant factor in cancer incidence.

The present review reveals that the St Lawrence population is the best studied cetacean population (as a proportion of the total population size) with respect to pathological studies.

The other major source of information was the AFIP database. This again clearly cannot be taken as providing a representative sample. It is by its nature confined to diseased animals submitted on a voluntary basis. Reasons for submission will be variable and unpredictable.

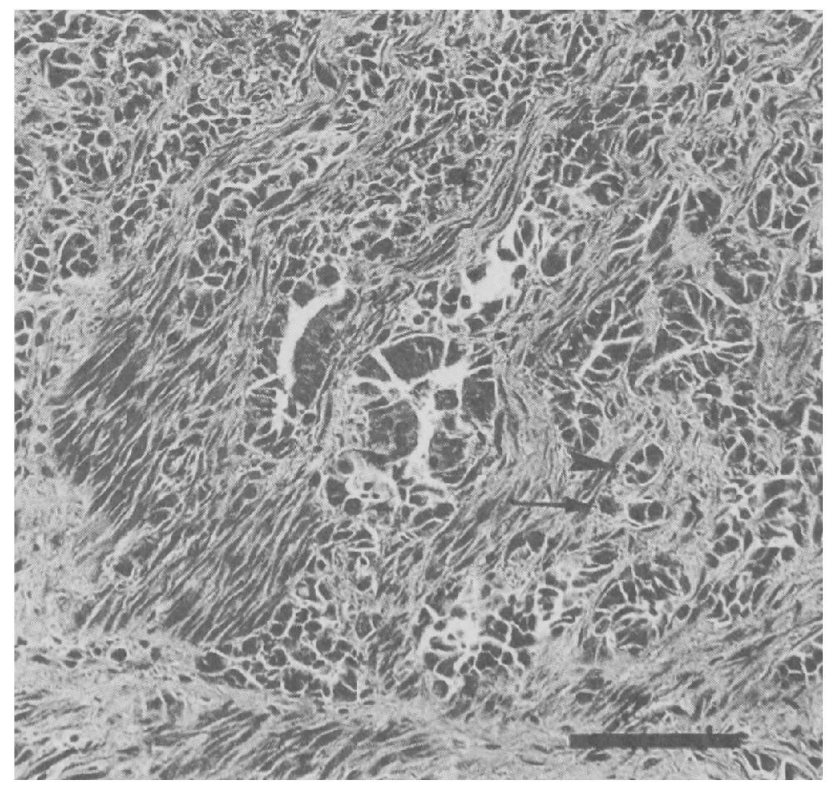

Fig. 4. Small intestinal (duodenal) adenocarcinoma in a beluga whale (DL-7-94). Tumour cells infiltrating the intestinal tunica muscularis tend to form glandular structures. Cellular nests (arrowhead) and individual tumour cells (arrow) are also observed. Note the loss of polarity of tumour cells and their markedly variable shape and size. Bar: 100 $4 \mathrm{~m}$. 
Cases are usually sent to the AFIP in order to obtain the opinion of the AFIP's pathologists and/or because the cases are unusual or otherwise of interest. Samples will be biased towards captive animals (of which the number of species is limited and which may also include animals kept for most, if not all of their life in an artificial environment) and stranded animals, and probably the North American region. There are a number of well-known problems in the interpretation of such data. Age data will be of varying sophistication (as witnessed in Table 3 where only one animal is of known age). This is not to suggest that the data are of no value but rather to insert a note of caution into their interpretation.

\section{Cancer incidence in the St Lawrence population}

In the 'Materials and Methods' section, a number of assumptions were identified in the calculation of AIR. The validity of these is discussed below.

\section{Can the St Laurence animals be considered a separate population?}

In veterinary, as in human epidemiology, the number of individuals at risk must be known precisely in order to determine the prevalence of disease. This requirement explains why there have been few epidemiological studies of cancer in wild mammals and especially in marine mammal populations, which are notoriously ill-defined and/or widespread.

However. the geographical isolation of the St Lawrence animals in a restricted, relatively small area at the southernmost range of the species means that they can be treated as a separate population (e.g. Bjørge et al., 1994, pp.83-4). This population is believed to have declined from an estimated 5,000 to about 500-1,000 animals (ibid., Table 9; Reeves and Mitchell, 1984), and is confined to a short stretch of the St Lawrence Estuary located downstream of a basin heavily contaminated by industrial pollutants. These whales have been the objects of numerous censuses, using a variety of techniques (Michaud et al., 1990; Kingsley and Hammill, 1991; Michaud, 1993). All recent censuses have provided results within approximately the same range (see Table 4).

\section{Are autopsied animals representative of the total population?}

The only criterion used to determine whether a given carcass was autopsied was its state of preservation. Thus, it does not seem unreasonable to assume that the autopsied animals represent an unbiased sample of the total stranded animals.

It is assumed that all carcasses have equal chances of being recovered and are examined whatever the cause of death for the following reasons. Given the restricted range of this population and the fact that all carcasses have been found within that range or downstream as a result of drifting (Michaud et al., 1990; Kingsley and Hammill, 1991; Michaud, 1993), apart from the winter period discussed above, it is probable that almost all deaths will result in detectable strandings. Thus, while some deaths may occasionally escape our attention, our

Table 4

Recent population estimates for the St Lawrence beluga population

\begin{tabular}{llcccl}
\hline Year & Method & Estimate & SE & $95 \%$ CI & Source \\
\hline 1988 & Photo & 491 & 69 & & Kingsley and Hammill, 1991 \\
1990 & Photo & 606 & 308 & & Kingsley and Hammill, 1991 \\
1992 & Visual & 490 & n/a & & Michaud, 1993 \\
1992 & Photo & 525 & 71 & $410-725$ & Kingsley, 1996 \\
1995 & Photo & 705 & 108 & $540-1035$ & Kingsley, 1996 \\
& Average & 563 & & & \\
\hline
\end{tabular}


Table 5

Calculation of AIR for the St Lawrence beluga population, including a crude sensitivity test to some of the assumptions made (see text).

\begin{tabular}{lrrr}
\hline & Pessimistic & 'Best' & Optimistic \\
\hline No. of autopsied animals with cancer & 14.00 & 14.00 & 14.00 \\
No. of autopsied animals & 73.00 & 73.00 & 73.00 \\
No. of stranded animals & 175.00 & 175.00 & 175.00 \\
Correction for poor weather & 1.50 & 1.33 & 1.00 \\
Estimated total mortality & 262.50 & 233.33 & 175.00 \\
Estimated no. of cancers in the population & 50.34 & 44.75 & 33.56 \\
Study period in years & 12.00 & 12.00 & 12.00 \\
Annual estimated no. cancers & 4.20 & 3.73 & 2.80 \\
Estimated total population size & 500.00 & 500.00 & $1,000.00$ \\
AIR & 839.04 & 745.81 & 279.68 \\
\hline
\end{tabular}

sampling is most likely representative of the population in terms of causes and extent of mortality (it is in practice a minimum total mortality). However, the correction used for poor weather may be biased downwards to an unknown degree in that it assumes equal mortality throughout the year, when in fact the poor weather may result in higher mortality during those months, as has been seen in some other odontocete species. The extreme ice and weather conditions found at that time of year effectively break down any carcasses into small pieces. Thus, the possibility that carcasses from animals that died during the winter period may still be available for detection, and thus allowed for twice, can be ruled out.

\section{Sensitivity of the results to the assumptions made}

Whilst the estimate of an AIR of about 750 per 100,000 individuals represents our best estimate, it is clear that this is assumption dependant. In order to examine the sensitivity of the estimate to the assumptions we have varied some of the parameter values used as shown in Table 4 . The table shows that the AIR is heavily dependent on the assumptions made. The crude sensitivity analysis shown in the table (which only examines questions of weather correction and population size) gives a range of AIR values from about 280-840.

\section{Comparison of St Lawrence Estuary heluga whales with other species/populations Cetaceans}

The present review has shown that $40 \%$ of the 35 cancers reported in cetaceans have been found in the St Lawrence beluga whale population. This dramatically high figure clearly needs to be interpreted with caution in view of the limitations of the source material discussed above. However, the cancer prevalence in this population is much higher than that observed in the albeit limited studies of other cetacean populations, including Arctic populations of the same species (D.J. St. Aubin, pers. comm. in De Guise et al., 1994).

Cancer is generally a disease of old age and thus a longer life expectancy for St Lawrence beluga whales might explain their high rate of cancer. All animals with cancer in our study were over 16 years. A comparison of the age composition of the 135 stranded St Lawrence whales of known age with that of 412 harvested belugas from the Alaskan population (Burns and Seaman, 1985) shows that there are older animals in the Alaskan population (Fig. 5). However, as one might expect, the stranded population is bimodal, with a peak of newborns and then one of older animals in the 18-26 age group, in contrast to the harvested population which is skewed towards younger animals with a single peak at around 6-8 years followed 


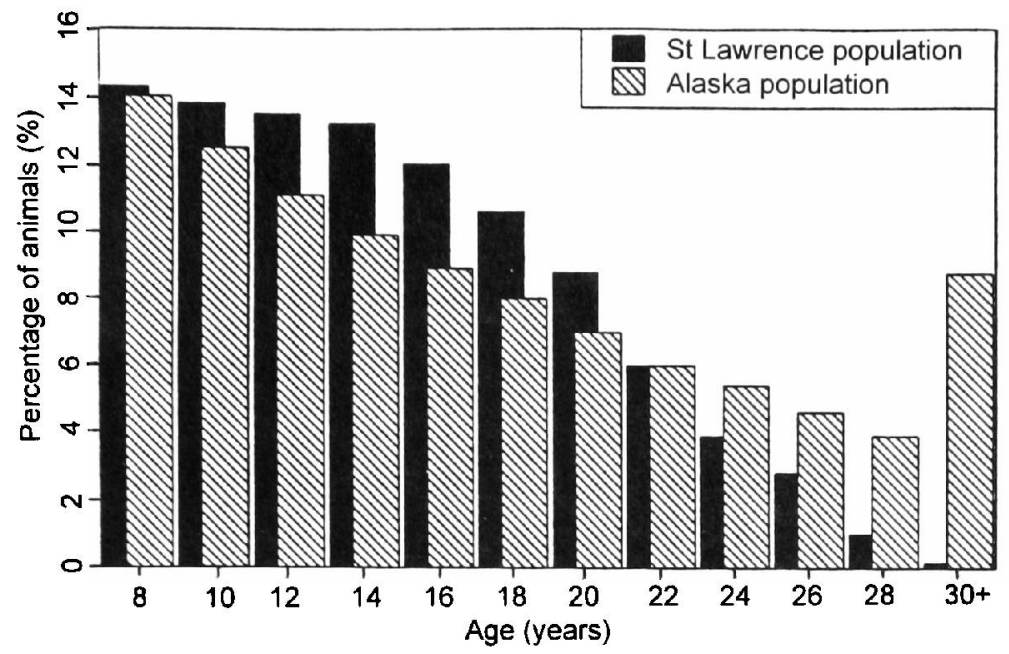

Fig. 5. Comparison of the age structure of the St Lawrence beluga whales (Béland et al., 1988) with the Alaskan population (Burns and Seaman, 1985) according to published life tables.

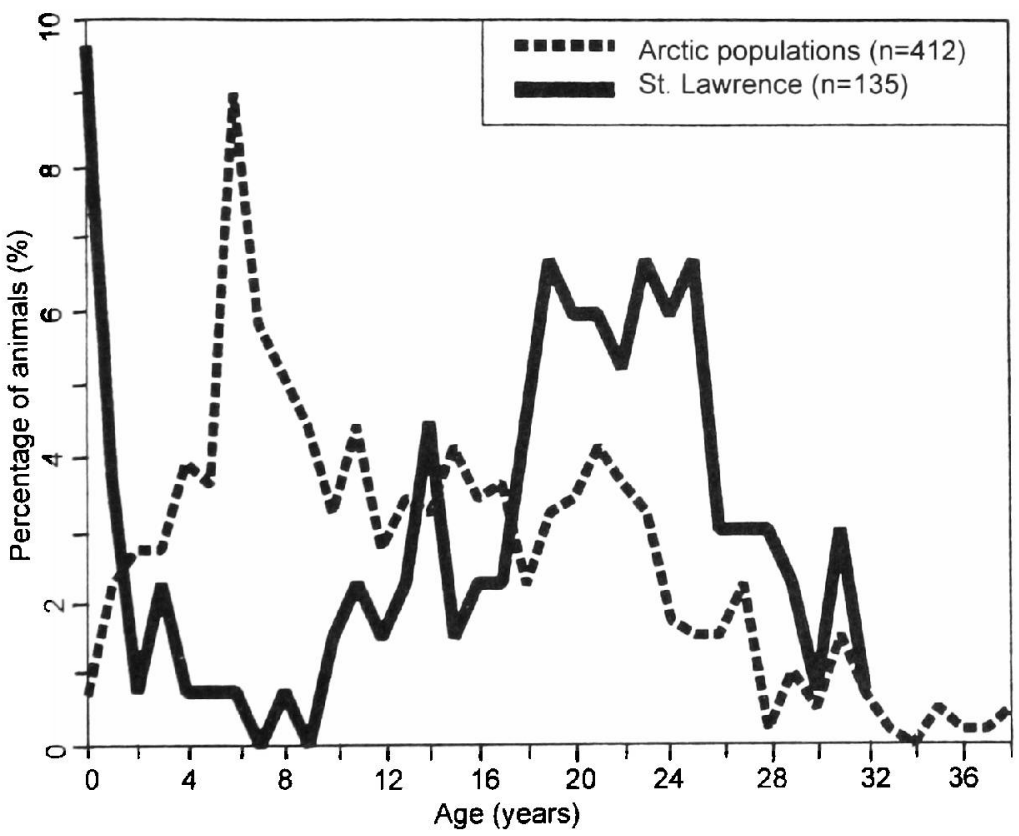

Fig. 6. Comparison of the age distribution of the St. Lawrence Estuary beluga whales found stranded (1983-1994) and the beluga whales sampled by aboriginal hunting in the Arctic (adapted from Burns and Seaman, 1985).

by a general decline (Fig.6). Without knowledge of the age structure of the Arctic population referred to (D.J. St Aubin pers. comm. in De Guise et al., 1994) it is difficult to make a strict comparison of those data with the St Lawrence data that is not potentially confounded by age. 


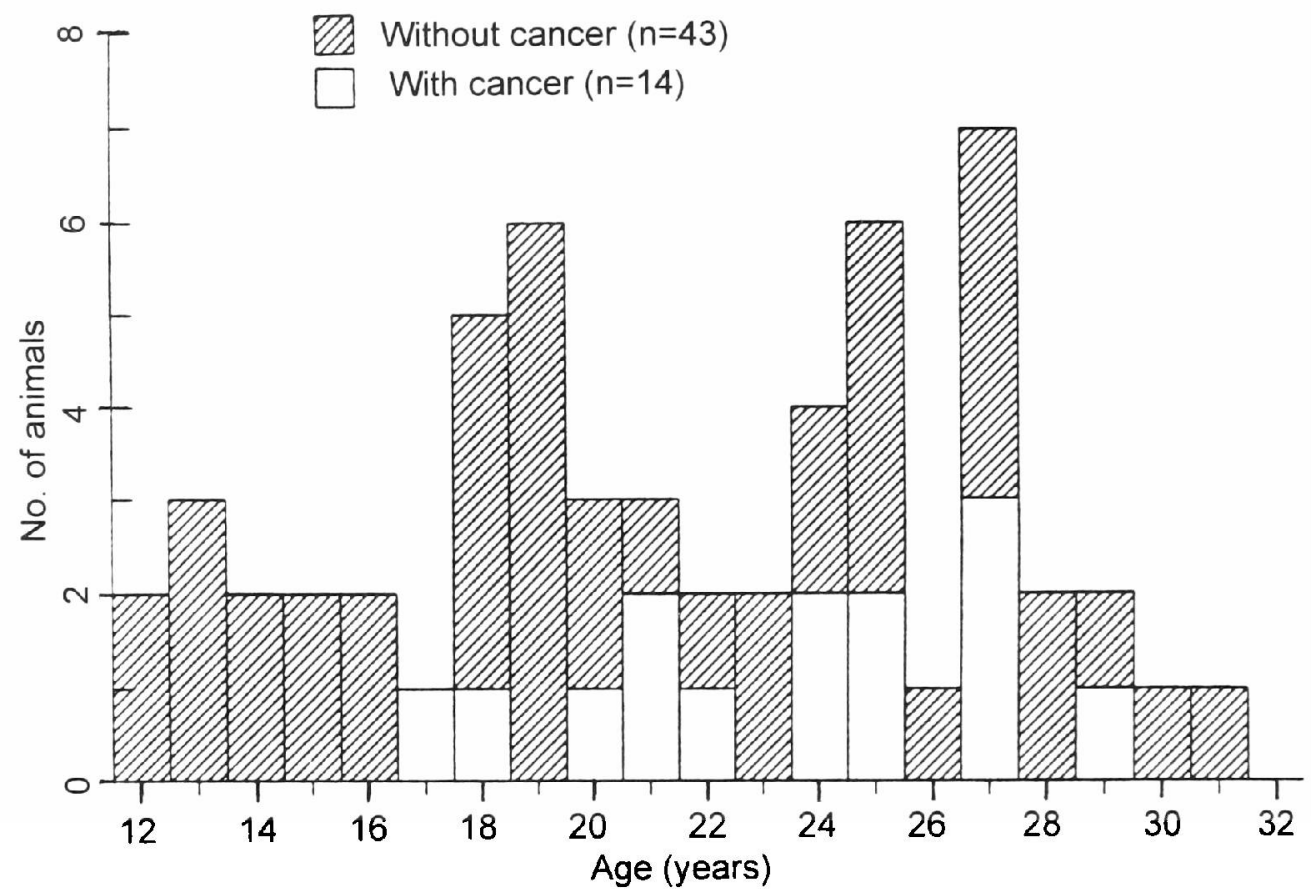

Fig. 7. Age distribution of stranded St Lawrence Estuary beluga whales with and without cancers and older than 12 years (1983-1994).

In mature whales (age 12 and older) with cancer and mature animals without cancers, the mean age of animals with cancer is 23.36 whereas that without is 20.84 (Fig.7). The difference is not significant at the $\mathrm{p}>0.10$ level.

Eight cases of cancers are reported among 834 cetaceans listed in the AFIP's Marine Mammal Database ( $1 \%$ ) (Table 3). Whilst this is significantly lower (chi-square $=86,81: 1 \mathrm{df}$. $\mathrm{p}<0.01$ ) than the incidence in the St Lawrence population, the limitations of this database referred to earlier render such statistical tests difficult to interpret in anything more than a general way. It might seem more appropriate to compare the St Lawrence population with only the 14 beluga whales ( 11 necropsy cases with 1 cancer and 3 surgical biopsy cases with no cancers) included in the database. However, all of the animals were captive and from a variety of populations, and given the small sample size, the fact that there is no significant difference (chi-squared test) between the frequency of cancer (1/11) among the necropsied APIF beluga whales and those from the St Lawrence again does not allow one to reach any firm conclusions.

\section{Other tatia}

The populations of domestic species used in epidemiologic studies are animals that were examined at veterinary collcges (Priester and Mantel. 1971: Priester and McKay, 1980). These are probably under better medical care and include more sick animals than the general animal population. In addition, the older animals are more numerous in the pet animal population owing to curative and preventative improvement in veterinary medicine (Dorn and Priester, 1987). 
Free-ranging animals generally have a shorter life span than captives because of predation, harsh environmental conditions and malnutrition. Since the risk of developing cancer increases with age, it is reasonable that cancer rates in pet, zoo and aquarium animals would be higher than in free-ranging mammals (Fowler, 1987). Yet, for all cancer types, our 'best' AIR estimate for St Lawrence belugas is much higher than that observed in horses and cats, is slightly lower than the rate observed in dogs and is twice that of man. Even if the 'optimistic' scenario is chosen, the value is comparable with that of cats and horses and close to that of man.

In addition, the rate of gastrointestinal cancers affecting St Lawrence belugas appears much higher than the rate observed in man and domestic species, with the exception of sheep in certain parts of the world. Thus, not only does this whale population appear to have a high prevalence of cancer, but this is particularly marked with regard to adenocarcinomas of the gastrointestinal tract (intestine, stomach and salivary glands); such tumours accounted for half of the malignant tumours found (Table 6).

Table 6

Frequency of cancer in St Lawrence estuary beluga whales over 12 years (1983-1994) compared to that of man and domestic animals. Estimated annual incidence rate of cancer per 100,000 animals (AIR).

\begin{tabular}{lccc}
\hline & Total cancer & Epithelial cancer of the small intestine & $\begin{array}{c}\text { Epithelial cancer of the gastrointestinal } \\
\text { tract }^{1}\end{array}$ \\
\hline Beluga & $233(750)^{2}$ & $83(266)^{7}$ & $117(327)$ \\
Man $^{3}$ & 363.4 & $67(212)^{8}$ & 55.6 \\
Cattle $^{4}$ & 177.2 & 0.8 & 2.78 \\
Dog $^{5}$ & 828.3 & 2.78 & 24.3 \\
Cat $^{5}$ & 257.4 & $6.87^{9}$ & 29.2 \\
Horse $^{5}$ & 256.3 & 26 & 7.7 \\
Sheep $^{6}$ & 0.03 & 0 & ND \\
\hline
\end{tabular}

${ }^{\prime}$ Gastrointestinal tract: glandular stomach, small and large intestine combined. '( ): AAIR: adjusted AIR accounting for mortality in winter months and for total mortality. 'Man (Anonymous, 1991; Anonymous, 1992). ${ }^{4}$ Cattle (Priester and Mantel, 1971; Pricster and McKay, 1980; Bristol et al., 1994). ${ }^{5}$ Dog, cat, horse (Priester and Mantel, 1971; Priester and McKay, 1980). ${ }^{6}$ Sheep (Georgsson and Vigfusson, 1973). ${ }^{7}$ Five cancers of the small intestine (if the most distal intestinal adenocarcinoma is considered as affecting the small intestine). ${ }^{8}$ Four cancers of the small intestine (if the most distal intestinal adenocarcinoma is considered as affecting the large, instead of the small intestine, Martineau et al., 1995). "Sum of epithelial cancers listed under 'small intestine' and 'intestine not otherwise specified' in Priester and McKay, 1980.

Several etiologies for the high prevalence of a specific cancer cell type in such a small population can be envisaged.

In cattle, small intestinal cancer results from an interaction between exogenous carcinogens and viruses. Bovine papillomavirus type-4 causes papillomas in the bovine upper digestive tract. In cattle infected with that virus and fed with bracken fern, a plant that contains powerful carcinogens, these benign tumours become malignant and are accompanied by intestinal adenomas and adenocarcinomas that do not contain viral DNA (Campo et al., 1994). thus, viral infection alone does not cause cancer. A similar interplay might be at work in St Lawrence belugas since gastric papillomatosis has been observed in a significant number of carcasses and particles consistent with papillomaviruses have been visualised in papillomas (Martineau et al., 1988; De Guise et al., 1994).

In contrast to their rarity in other animals, high prevalences $(0.2-1.58 \%)$ of intestinal adenocarcinomas are observed in sheep in some regions of Australia and New Zealand. 
Ingestion of environmental carcinogens, particularly phenoxy and picolinic acid herbicides, are thought to be major etiological factors of these endemic cancers (e.g. Dodd, 1960; Webster, 1966; Cordes and Shortridge, 1971; Georgsson and Vigfusson, 1973). Carcinogens are also present in the environment of St Lawrence belugas and are probably ingested by these animals. The Saguenay River is part of the St Lawrence belugas' habitat. Its sediments contain 500-4,500ppb of total polycyclic aromatic hydrocarbons (PAH) (dry weight) (Martel et al., 1986). Benzopyrene DNA adducts were detected in St Lawrence beluga tissues, and were absent from the brain and liver of four Arctic whales (Mackenzie Estuary) (Shugart et al., 1990). Beluga whales, unique among odontoceti in that regard, are known to feed in significant amounts on bottom invertebrates (Vladykov, 1944; 1946). They dive comfortably down to 400 meters (Ridgway et al., 1984). In addition, field observations suggest that these whales dig into sediments (Dalcourt et al., 1992). Considered together, these observations suggest that St Lawrence belugas ingest carcinogenic compounds, which might explain the high rate of digestive tract cancers seen in this population.

This situation would not be without precedent. In bottom-dwelling fish, labial papilloma and liver cancer are strongly associated with chemical contamination of sediments (Harshbarger and Clark, 1990). Interestingly, in humans, gastric cancers and the rare epithelial cancers of small intestines have been associated with the ingestion of smoked food, which are contaminated with benzopyrene (Chow et al., 1993).

That small intestinal cancer might be a feature of beluga whales as a species appears unlikely; the presence of only a single case of cancer (not intestinal) among the 17 beluga whales listed in the Marine Mammal Database and the absence of this condition in the literature do not support this hypothesis.

Inbreeding has led to some degree of genetic homogeneity in St Lawrence belugas (Patenaude et al., 1994). Cancers have not been reported in genetically highly homogenous wild animals such as free-ranging cheetahs and Florida panthers (O'Brien, 1994). In man, rare forms of cancers are known to be inherited (Cotran et al., 1994). However, in free-ranging animal populations there are no reports which document genetic susceptibility to certain types of cancers, although some reports do suggest that such susceptibility concerns free-ranging animals that have been kept in captivity for months or years (Carpenter et al., 1981).

\section{CONCLUSION}

This paper has highlighted the limited amount of data available on cancer in cetaceans that can be used in a rigorous quantitative manner. Despite this, it is clear from examining the available data from cetaceans and other mammals, that there appears to be an unusually high incidence of cancer in the St Lawrence beluga population. There is evidence to suggest that this may be related to chemical pollutants but the difficulties of establishing such a cause-effect relationship are well-known and will require a major dedicated research programme (see Reijnders et al., 1999).

Convincing statistics would require much larger numbers of whales and/or the follow-up of St Lawrence belugas for many more decades. These are drawbacks that have long been recognised by cancer epidemiologists and that have been partly solved by studying large numbers of bottom-dwelling fish (Harshbarger and Clark, 1990) or small numbers of dogs in well designed epidemiological studies using age, breed and sex-matched controls. In the latter studies, cancer specific types have been associated with exposure to asbestos and insecticides (e.g. Glickman et al., 1983; 1989; Hayes et al., 1991).

The observation of high cancer prevalences in other populations of marine mammals similarly exposed to carcinogens would strengthen an etiological relation with chemical 
carcinogenesis (Fox, 1991). Such observations have recently been made; 65 cases of metastatic carcinomas have been reported in 370 California sea lions stranded alive from 1979 to 1994 along the Californian coast (7.6\% of necropsied animals) (Gulland et al., 1996) and in eight adult sea lions out of 82 (9.7\% of necropsied animals) in 1993-94 (Holshuh et al., 1995). In both instances, exogenous carcinogens have been considered as possible etiological agents.

The etiological role of contaminants in cancer of marine mammals would be supported by the absence of tumours in stranded animals from non-exposed populations and by the detection of specific, identical mutations in genes such as ras or p53 in tumours. The possible contribution of other factors to the etiology of cancer in St Lawrence belugas such as genetic homogeneity and viruses should also be examined.

\section{Acknowledgments}

We wish to thank Bruce Williams from the Department of Veterinary Pathology, AFIP, for his help, B. Clausen from the Environmental Investigation Agency, the Ministry of Environment, Government of Denmark and Greg Donovan of the International Whaling Commission for reviewing the manuscript and providing useful comments.

\section{REFERENCES}

Anonymous. 1991. Cancer in Canada. 1985, 1986. Health Report 3(2):104.

Anonymous. 1992. Statistiques Canadiennes sur le Cancer, 1992. Institut National du Cancer du Canada, Toronto, Canada. 65pp.

Baker, J.R. and Martin, A.R. 1992. Causes of mortality and parasites and incidental lesions in harbour porpoises (Phocoena phocoena) from British waters. Vet. Rec. 130:554-8.

Béland, P., Vezina, A. and Martineau, D. 1988. Potential for growth of the St. Lawrence (Quebec, Canada) beluga whale (Delphinapterus leucas) population based on modelling. J. Cons. Int. Explor. Mer 45:22-32.

Benirschke, K. and Marsh, H. 1984. Anatomic and pathologic observations of female reproductive organs in the short-finned pilot whale, Globicephala macrorhynchus. Rep. int. Whal. Commn (special issue) 6:451-5.

Bjørge, A., Brownell, R.L.J., Donovan, G.P. and Perrin, W.F. 1994. Significant direct and incidental catches of small cetaceans. A report by the Scientific Committee of the International Whaling Commission to the United Nations Conference on Environment and Development (UNCED). Rep. int. Whal. Commn (special issue) 15:75-130.

Breuer, E.M., Krebs, B.H. and Hofmeister, R.J. 1989. Metastasizing adenocarcinoma of the stomach in a harbour porpoise. Dis. Aquat. Org. 7:159-63.

Bristol, D., Baum, K.H. and Mezza, L.E. 1994. Adenocarcinoma of the jejunum in two cows. J. Am. Vet. Med. Assoc, 185:551-3.

Burns, J.J. and Seaman, G.A. 1985. Investigations of beluka whales in coastal waters of western and northern Alaksa. II. Biology and ecology. Final report for US Dept Commerce, NOAA, under contract no. 81 RAC 00049 (unpublished). 129pp. [Available from the author].

Campo, M.S., O'Neil, B.W., Barron, R.J. and Jarrett, W.F. 1994. Experimental reproduction of the papilloma-carcinoma complex of the alimentary canal in cattle. Carcinogenesis 15:1,597-601.

Carpenter, J.W., Novilla, M.N. and Kaiser, H.E. 1981. Neoplasia and other disease problems in black-footed ferrets: implication for an endangered species. pp. 739-46. In: H.E. Kaiser (ed.) Neoplasms-Comparative Pathology of Growth in Animals, Plants, and Man. Williams and Wilkins Co, Baltimore, MD. 908.

Chow, W.-H., Linet, M.S., McLaughlin, J.K., Hsing, A.W., Co Chien, H.T. and Blot, W.J. 1993. Risk factors for small intestine cancer. Cancer Causes and Control 4:163-9.

Cordes, D.O. and Shortridge, E.H. 1971. Neoplasms of sheep: a survey of 256 cases recorded at Ruakura Animal Health Laboratory. N.Z. Vet. J. 19:55-64.

Cotran, R.S., Kumar, V. and Robbins, S.L. 1994. Neoplasia. pp. 241-303. In: R.S. Cotran, V. Kumar and S.L. Robbins (eds.) Pathologic Basis of Disease. W.B. Saunders, Philadelphia. 1,400pp.

Dalcourt, M.F., Béland, P., Pelletier, E. and Vigneault, Y. 1992. Caractérisation des communautés benthiques et étude des contaminants dans des aires fréquentées par le béluga du Saint-Laurent. Rapp. Tech. Can. Sci. Halieut. Aquat. 1845:i-vii+86. 
De Guise, S., Lagacé, A. and Béland, P. 1994. Tumors in St. Lawrence beluga whales (Delphinapterus leucas). Vet. Pathol. 31(4):444-9.

Dodd, D.C. 1960. Adenocarcinoma of the small intestine of sheep. N.Z. Vet. J. 8:109-12.

Dorn, C.R. and Priester, W.A. 1987. Epidemiology. pp. 27-52. In: G.H. Theilen and B.R. Madewell (eds.) Veterinary Cancer Medicine. Lea \& Febiger, Philadelphia, PA. 676pp.

Fowler, M.E. 1987. Zoo animals and wildlife. pp. 649-62. In: G.H. Theilen and B.R. Madewell (eds.) Veterinary Cancer Medicine. Lea \& Febiger, Philadelphia, PA. 676pp.

Fox, G.A. 1991. Practical causal inference for ecoepidemiologists. I. Toxicol. Environ. Health 33:359-73.

Georgsson, G. and Vigfusson, H. 1973. Carcinoma of the small intestine of sheep in Iceland. A pathological and epizootiological study. Acta l'et. Scand. 14:392-409.

Geraci, J.R., Palmer, N.C. and St Aubin, D.J. 1987. Tumors in cetaceans: analysis and new findings. Can. J. Fish. Aquat. Sci. 44(7):1289-300.

Girard, C., Lagacé, A., Higgins, R. and Béland, P. 1991. Adenocarcinoma of the salivary gland in a beluga whale (Delphinapterus leucas). J. Vet. Diagn. Invest. 3:264-5.

Glickman, L.T., Domanski, L.M., Maguire, T.G., Dubielzig, R.R. and Churg, A. 1983. Mesothelioma in pet dogs associated with exposure of their owners to asbestos. Environ. Res. 32:305-13

Glickman, L.T., Schofer, F.S., McKee, L.J., Reif, J.S. and Goldschmidt, M.H. 1989. Epidemiologic study of insecticide exposures, obesity, and risk of bladder cancer in household dogs. J. Toxicol. Emiron. Health 28:407-14.

Gulland, F., Trupkiewicz, J. and Lowenstine, L. 1996. Metastatic carcinoma of probable transitional cell origin in 66 free-living California Sea Lions (Zalophus califormianus) 1979-1994. J. Wildl. Dis. :In press.

Harshbarger, J.C. and Clark, J.B. 1990. Epizootiology of neoplasms in bony fish of North America. Sci. Total Environ. 94:1-32.

Hayes, H.M., Tarone, R.E., Cantor, K.P., Jessen, C.R., McCurnin, D.M. and Richardson. R.C. 1991. Case-control study of canine malignant lymphoma: positive association with dog owner's use of 2,4-dichlorophenoxyacetic acid herbicides. J. Natl Canc'er Inst. 83:1226-31.

Holshuh, H.J., Zumwalt, D.D. and Ott, J.M. 1995. Disseminated carcinomatosis in stranded California sea lions (Zalophus californianus), Southern California, 1994. Paper presented at the Joint Conference of the American Association of Zoo Veterinarians, the Wildlife Disease Association and the American Association of Wildlife Veterinarians, East Lansing. Michigan, August 1995 (unpublished). 538pp. [Available from author].

Howard, E.B., Britt Jr, J.O. and Simpson, J.G. 1983. Neoplasms in marine mammals. pp. 95-162. In: E.B. Howard (ed.) Vol. II. Pathobiology of Marine Mammal Diseases. CRC Press, Boca Raton. $\mathrm{i}-\mathrm{xii}+233 \mathrm{pp}$.

Kingsley, M.C.S. 1996. Population index estimate for belugas of the St Lawrence in 1995. Can Tech. Rep. Fish. Aquatic Sci. 2117. 38pp.

Kingsley, M.C.S. and Hammill, M.O. 1991. Photographic census surveys of the St. Lawrence population. 1988 and 1990. Rapp. Te'h. Cam. Sci. Halieut. Aquan. 1776:1-19.

Landy, R.B. 1980. A review of neoplasia in marine mammals (Pinnipedia and Cetacea). Pp. 579-91. Im: R.J. Montali and G. Migaki (eds.) The Comparative Pathology of Zoo Animals. Smithsonian Institution Press. Washington. 684pp.

Martel, L.M., Gagnon, J., Massé, R., Leclerc, A. and Tremblay. L. 1986. Polycyclic aromatic hydrocarbons in sediments from the Saguenay fjord, Canada. Bull. Environ. Comtam. Toricol. 37:133-40.

Martineau, D., Lagacé, A., Massé, R., Morin, M. and Béland, P. 1985. Transitional cell carcinoma of the urinary bladder in a beluga whale (Delphinapterus leucus). Can. I't. J. 26:297-302.

Martineau, D., Lagacé, A., Béland, P., Higgins, R., Armstrong, D. and Shugart, L.R. 1988. Pathology of stranded beluga whales (De/phinapterus leucas) from St Lawrence Estuary (Québec, Canada). J. Comp. Pathol. 38:287-311.

Martineau, D., De Guise, S., Fournier, M.. Shugart. L.. Girard. C.. Lagacé, A. and Béland, P. 1994. Pathology and toxicology of beluga whales from the St Lawrence estuary, Quebec. Canada - past, present and future. Sci. Total Environ. 154(2-3):201-15.

Martineau, D., Lair, S., De Guise, S. and Béland, P. 1995. Intestinal adenocircinomas in two beluga whales (Delphinapterus leucas) from the Estuary of the St. Lawrence River. Can. V't. J. 36:563-5.

Michaud, R. 1993. Distribution estivale du béluga du Saint-Laurent; synthèse 1986 à 1992. Rapl. Torh. Can. Sci. Halicut. Aquar. 1906:i-x+22. [In Frenchl.

Michaud. R., Vézina. A., Rondeau, N. and Vigneault, Y. 1990. Distribution annuelle et caractérisation préliminaire de's habitals du béluga (Delphimapterus leucas) du Saint-Laurent. (an. J. Fish. Aquat. Sci. 1756:v+31. [In French].

O'Bricn, S.J. 1994. A role for molecular genetics in biological conservation. Proc. Natl Acad. Sci, USA 91:5748-55. 
Patenaude, N.J., Quinn, J.S., Béland, P., Kingsley, M. and White, B.N. 1994. Genetic variation of the St. Lawrence beluga whale population assessed by DNA fingerprinting. Mol. Ecol. 3:375-81.

Philo, L.M., Shotts, E.B. and George, J.C. 1993. Morbidity and mortality. pp. 275-312. In: J.J. Burns, J.J. Montague and C.J. Cowles (eds.) Special Publication. No. 2. The Bowhead Whale. 1st. Edn. Society for Marine Mammalogy, Lawrence, Kansas.

Priester, W.A. and Mantel, N. 1971. Occurrence of tumors in domestic animals. Data from 12 United States and Canadian colleges of veterinary medicine. J. Natl Cance' Inst. 47:1333-44.

Priester. W.A. and McKay, F.W. 1980. The Occurrence of Tumors in Domestic Animals. National Cancer Institutes. Monograph 54. US Department of Health and Human Services, Public Health Service, National Institutes of Health, Washington, DC. $210 \mathrm{pp}$.

Reeves, R.R. and Mitchell, E. 1984. Catch history and initial population of white whales (Delphinapterus leucas) in the River and Gulf of St. Lawrence, eastern Canada. Nat. Can. (Rev. Ecol. Syst.) $111: 63-121$.

Reijnders, P.J.H., Donovan, G.P., Aguilar, A. and Bjørge, A. 1999. Report of the IWC Workshop on Chemical Pollution and Cetaceans. J. Cetacean Res. Manage. (special issue 1):1-42.

Rewell, R.E. and Willis, R.A. 1949. Some tumours found in whales. J. Pathol. Bacteriol. 61:454-6.

Ridgway, S.H., Bowers, C.A., Miller, D., Schultz, M.L., Jacobs, C.A. and Dooley, C.A. 1984. Diving and blood oxygen of the white whale. Can. J. Zool. 62(11):2349-51.

Shugart. L.R., Martineau, D. and Béland, P. 1990. Detection and quantification of benzo(a)pyrene adducts in brain and liver tissues of beluga whales (Delphinapterus leucas) from the St. Lawrence and Mackenzie estuaries. pp. 219-23. In: J. Prescott and M. Gauquelin (eds.) Proceedings, International Forum for the Future of the Beluga. Presses Université du Québec, Sillery, Québec. i-xxxii+345pp.

Stolk, A. 1952. Tumours in whales. Amsterdam Natu. 1:28-33.

Stroud, R.K. and Roffe, T.J. 1979. Causes of death in marine mammals stranded along the Oregon coast. J. Wildl. Dis. 15:91-7.

Vladykov, V.D. 1944. Chasse et Biologie du Marsouin blanc. Fisheries Department, Province of Quebec. $194 \mathrm{pp}$.

Vladykov, V.D. 1946. Études sur les mammifères aquatiques IV. Nourriture du marsouin blanc ou béluga (Delphinapterus leucas) du fleuve Saint-Laurent. Contrib. Dép. Pêch. 17:1-155.

Webster, W.M. 1966. Neoplasia in food animals with a special reference to the high incidence in sheep. $N . Z$. Vet. J. 14:203-14.

Yonezawa, M., Nakamine, H., Tanaka, T. and Miyaji, T. 1989. Hodgkin's disease in a killer whale (Orcinus orca). J. Comp. Pathol. 100(2):203-7. 